\title{
Genetic improvement of microorganisms for applications in biorefineries
}

\author{
Bárbara G Paes ${ }^{1,2}$ and João RM Almeida ${ }^{2 *}$
}

\begin{abstract}
The development of biorefineries directed to the production of fuels, chemicals and energy is important to reduce economic dependence and environmental impacts of a petroleum-based economy. Microorganisms are essential in several industrial bioprocesses nowadays, and it is expected that new microbial bioprocesses will play a key role in biorefineries. However, the bioconversion process requires a robust and highly productive microorganism. In this scenario, several strategies to genetically improve microorganisms to overcome the bioprocesses challenges have been considered. In this work, we review microorganisms importance in the biorefineries concept, highlight the desirable traits they must hold in order to be employed, and discuss the main strategies to improve such traits. The focuses of this work are on four main targets in the improvement of microorganisms: driving carbon flux towards the desired pathway, increasing tolerance to toxic compounds, increasing substrate uptake range and new products generation.
\end{abstract}

Keywords: Microorganisms; Biorefineries; Bioprocess; Metabolic engineering; Genetic engineering; Evolutionary engineering

\section{Introduction}

The interest in renewable and sustainable biotechnological processes for energy, biofuels and chemicals production has been increasing over the years. Economical and environmental factors have been pushing the chemical industry, for instance, to invest in new means to get the same products in a more sustainable and economical way. It is estimated that by $2025,15 \%$ of global chemical sales will be bioderived [1]. In this context, the development of biorefineries appears as an important alternative to the common known petroleum-based processes and products. Biorefineries can be defined as "the sustainable processing of biomass into a spectrum of marketable products (food, feed, material, chemicals) and energy (fuels, power, heat) [2]. Chemical, physical and biological processes can be employed in a biorefinery to convert biomass into a large spectrum of products of interest [2]. The biorefinery concept is attractive because it would allow production of high added-value compounds and/or big volumes of biofuels, with market competitive prices, while reducing waste disposal and energy costs. In addition, always taking into consideration the

\footnotetext{
* Correspondence: joao.almeida@embrapa.br

Embrapa Agroenergy, Parque Estação Biológica W3 Norte, 70770-901 Brasília, DF, Brazil

Full list of author information is available at the end of the article
}

sustainability of the process and its indirect impacts (such as water use, impact on soil and biodiversity and competition for food). Few biorefineries have been in operation for several years, for instance, the pulp and paper based biorefinery Borregaard, in Norway [3], but there is still immense potential to be developed in several countries [2].

Microorganisms are main characters in industrial bioprocesses, being directly responsible for the production of the desired chemical, or indirectly providing important components for the processes. Indeed, there are several industrial processes in operation around the world based on microorganisms for production of food additives, enzymes and chemicals; for instance, the bioethanol industry from sugarcane in Brazil. Due to their versatility, microorganisms are also expected to play an essential role in conversion processes employed in biorefineries.

The development of biorefineries brings new opportunities and challenges to the industrial application of microorganisms. New substrates may be used and a variety of products formed; however, strains adapted to the industrial processes need to be developed. Based on the feedstock characteristics and desired products, a microbial strain and a production process optimization are needed to achieve an ideal conversion process (Figure 1). This led research groups from several institutions 


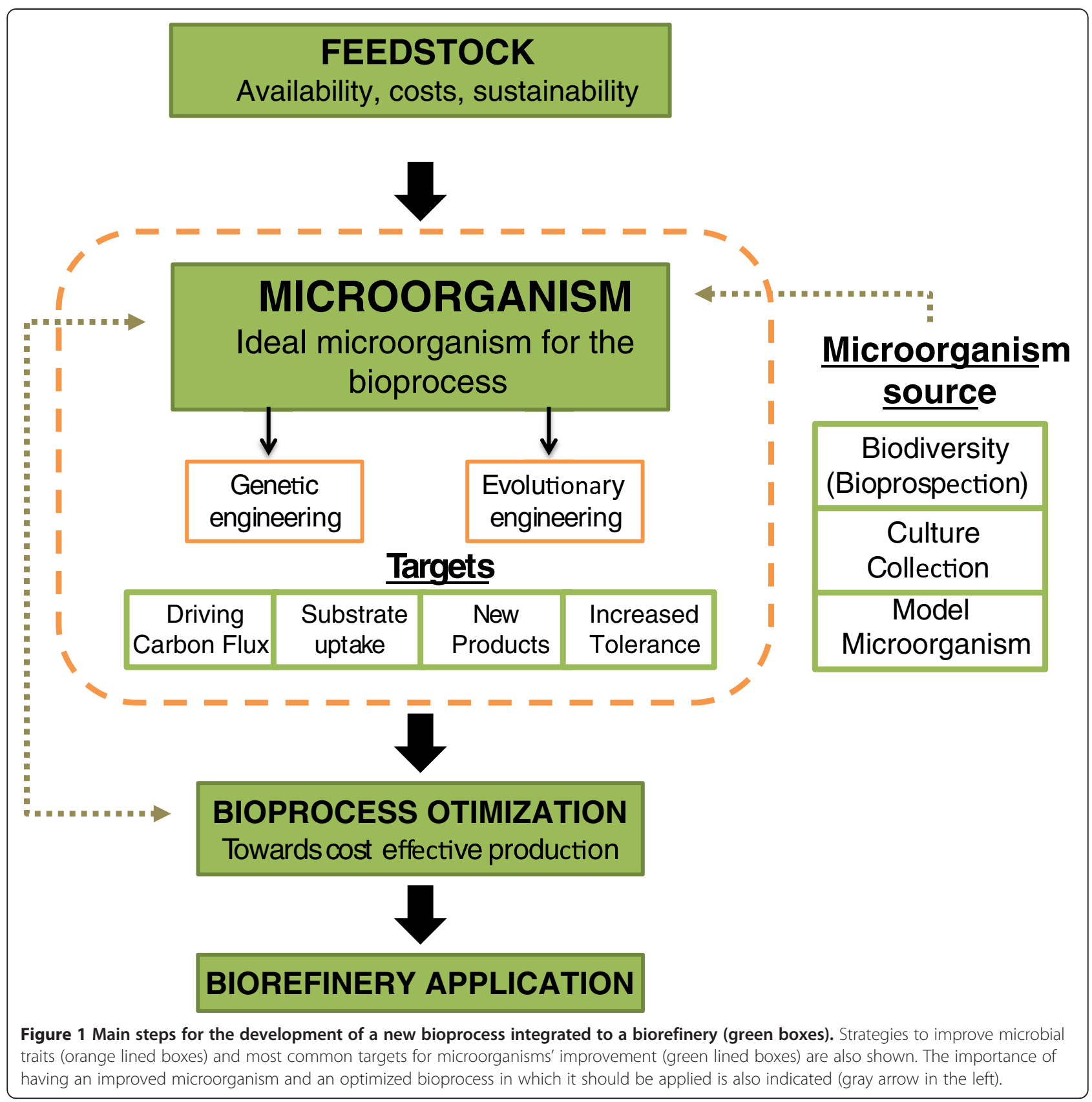

worldwide to start developing microbial strains for application in biorefineries and nowadays there are many promising experimental processes being developed. This work focuses on the importance of microorganisms in industries, summarizes and discusses the main targets for microbial improvement and the strategies currently employed to generate and improve strains to achieve commercial, technological and environmentally viable industrial processes (Figure 1). In addition, we highlight and exemplify general strategies to develop microorganisms that are able to produce fuels and chemicals from renewable feedstocks.

\section{Review}

Microorganisms currently used and new from biodiversity In order for a microorganism to be applied in a bioprocess, it must present specific traits, which would allow its maximum performance, i.e. high production yields and rates, even when submitted to one or a series of challenges. These may include substrate and product toxicity, variations or extreme $\mathrm{pH}$ values, high or variable temperature and pressure values, presence of competitors (biological or chemical contamination), inability to use all components of the substrate, and others [4]. It will be rather difficult to find a microorganism that has naturally all necessary traits to be 
employed in an industrial bioprocess. Therefore, genetic improvements of microorganisms have become an essential step in the development of such processes (Figure 1).

Genetically, physiologically and biologically wellcharacterized microorganisms, such as the yeast Saccharomyces cerevisiae, the bacteria Escherichia coli and other microorganisms which are also already employed commercially, are frequently the initial choice for the development of novel biocatalysts for industrial application. Previous knowledge about such microbes would ease the task of genetic improvement and the industrial utilization of new strains.

The yeast $S$. cerevisiae is the eukaryotic model microorganism and it is commonly utilized in bioethanol, brewery and bakers industries worldwide. In addition, several new bioprocesses for fuels and chemicals production are being developed based on this yeast [4] (Figure 2). It presents high level of ethanol tolerance (i.e. product inhibition is absent or minimal), ability to grow under different aeration conditions, including strictly anaerobic (which makes the process more easily controlled), have little nutrition requirements, shows high tolerance to toxic compounds and low $\mathrm{pH}$ tolerance, which also contributes to prevent bacterial contamination [5]. The accumulated knowledge about $S$. cerevisiae surpasses any other eukaryotic species. In fact, $S$. cerevisiae's genome was the first eukaryotic genome to be completely sequenced [6]. More recently, systems biology tools are abundantly available and further studies have been improving the understanding about this organism. Indeed, S. cerevisiae has been genetically modified to produce a variety of chemical products (Table 1 and Figure 2).

While $S$. cerevisiae is the eukaryotic model organism, E. coli stands as the prokaryotic one. Similarly to the yeast, its genetics, physiology and biology are wellknown, and genetic manipulation tools are already well established for it. E. coli's complete genome was published in 1997 [24]. E. coli has been genetically modified to produce many different chemical compounds (Table 1 and Figure 2) [25] demonstrating its biotechnological potential. Having many characteristics of interest to industry, such as efficient growth under industrial conditions, low nutritional requirements, anaerobic growth, capacity to use many different carbon sources including carbohydrates, polyols, and fatty acids [26] , this bacterium was already engineered to produce ethanol from lignocellulose [27] and it is currently employed in a bioethanol pilot plant in Florida [28].

The accumulated knowledge about such "model" microorganisms, in the most different subjects of studies, and familiarization with their requirements and performance, facilitates the task of genetic improvement and eases the industrial utilization of new strains. However, identification of new microorganisms, new genes and enzymes from the microbial biodiversity, still remains essential to reveal new traits and capabilities to favor development of biotechnological applications [29]. This becomes more relevant because estimates point

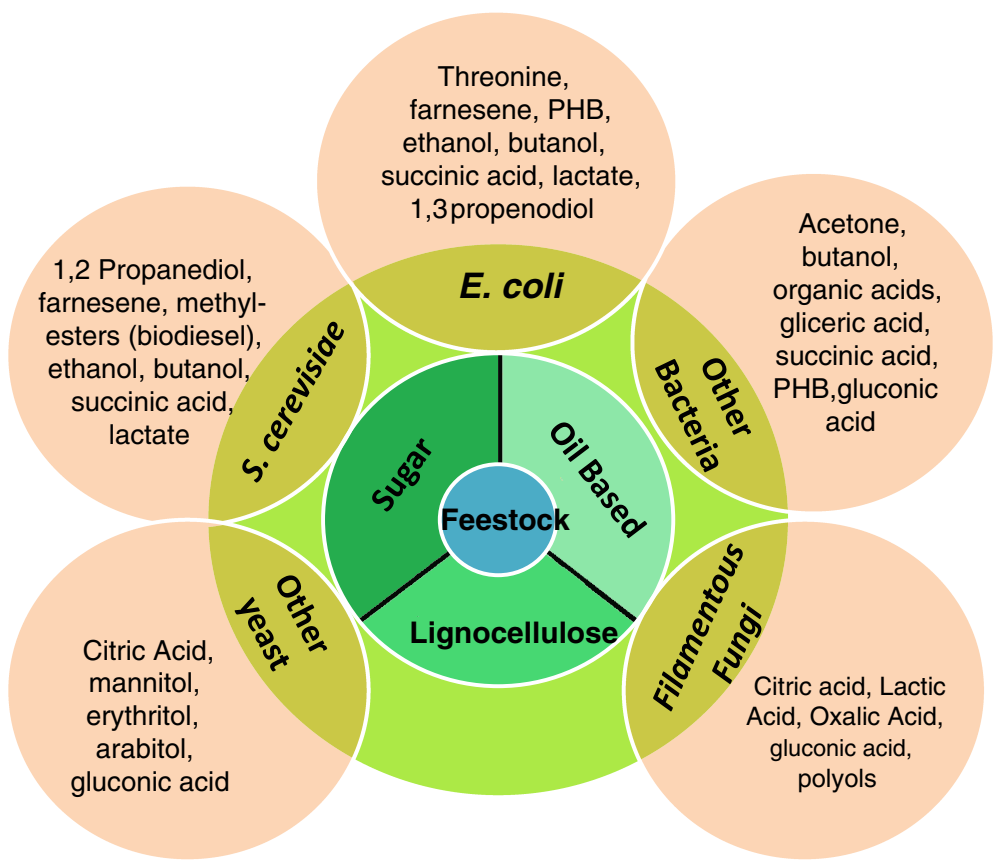

Figure 2 Examples of biofuels and chemicals produced from renewable feedstock by microbial strains. Detailed information about microbial strains and their production capacity can be found at 3, 8, 21, 29, 32, 34 and references there in. 
Table 1 Selected examples of four major target categories where genetic engineering strategies were applied to improve product formation by

\section{microorganisms}

\begin{tabular}{|c|c|c|c|c|c|c|c|}
\hline Organism & Product & Main substrate & Yield* & Productivity & Concentration & Outcomes & Main genetic modifications \\
\hline \multicolumn{8}{|c|}{ Driving carbon flux towards the desired pathway } \\
\hline E. colisY4 & Ethanol & Glycerol & $0.42 \mathrm{~g} \mathrm{~g}^{-1}$ & $0.15 \mathrm{~g} \mathrm{~L}^{-1} \mathrm{~h}^{-1}$ & $7.8 \mathrm{~g} \mathrm{~L}^{-1}$ & $\begin{array}{l}\text { Yield improved } 69 \text { fold. Engineered } \\
\text { strains efficiently utilized glycerol in } \\
\text { a minimal medium without rich } \\
\text { supplements }\end{array}$ & $\begin{array}{l}\text { Deletion of genes to minimize } \\
\text { the synthesis of by-products }\end{array}$ \\
\hline E. coli LA02 $\triangle$ dld & Lactic acid & Glycerol & $0.80 \mathrm{~g} \mathrm{~g}^{-1}$ & $1.25 \mathrm{~g} \mathrm{~g}^{-1} \mathrm{~h}^{-1}$ & $32 \mathrm{~g} \mathrm{~L}^{-1}$ & $\begin{array}{l}\text { Low-value glycerol streams to a } \\
\text { higher- value product like D-lactate. } \\
\text { Yield improved seven fold }\end{array}$ & $\begin{array}{l}\text { Overexpression of pathways } \\
\text { involved in the conversion } \\
\text { of glycerol to lactic acid and } \\
\text { blocking those leading to the } \\
\text { synthesis of competing } \\
\text { by-products }\end{array}$ \\
\hline E. coli & Acetate & Glucose & $0.456 \mathrm{~g} \mathrm{~g}^{-1}$ & $1.38 \mathrm{~g} \mathrm{~g}^{-1} \mathrm{~h}^{-1}$ & $53 \mathrm{~g} \mathrm{~L}^{-1}$ & $\begin{array}{l}\text { Reduction of the fermentation by } \\
\text { products concentration by 1, } 25 \\
\text { (succinate) to } 33 \text { fold (lactate). Yield } \\
\text { improved over seven fold }\end{array}$ & $\begin{array}{l}\text { Deletion of genes involved } \\
\text { in the succinate formation as } \\
\text { fermentation product }\end{array}$ \\
\hline Y. lipolytica & Succinic acid & Glycerol & $0.45 \mathrm{~g} \mathrm{~g}^{-1}$ & n.d & $45 \mathrm{~g} \mathrm{~L}^{-1}$ & $\begin{array}{l}\text { Succinic acid production yield } \\
\text { increased over } 20 \text { fold }\end{array}$ & $\begin{array}{l}\text { Deletion in the gene coding } \\
\text { one of succinate dehydrogenase } \\
\text { subunits }\end{array}$ \\
\hline \multicolumn{8}{|l|}{ Y-3314 } \\
\hline Mannheimia succiniciproducens & Succinic Acid & Glucose & $0.76 \mathrm{~g} \mathrm{~g}^{-1}$ & $1.8 \mathrm{~g} \mathrm{~g}^{-1} \mathrm{~h}^{-1}$ & $52.4 \mathrm{~g} \mathrm{~L}^{-1}$ & $\begin{array}{l}\text { Nearly complete elimination of } \\
\text { fermentation by-products, (acetic, } \\
\text { formic, and lactic acids) and carbon } \\
\text { recovery increased to } 58 \% \text { to } 77 \% \\
\text { by fed-batch culture }\end{array}$ & $\begin{array}{l}\text { Disruption of genes responsible } \\
\text { for by product formation (IdhA, } \\
\text { pflB, pta, and } a c k A \text { ) }\end{array}$ \\
\hline \multicolumn{8}{|c|}{ Increasing of tolerance to toxic compounds } \\
\hline C. acetobutylicum & Butanol & Glucose & n.d. & n.d. & & $\begin{array}{l}\text { Increased tolerance and extended } \\
\text { metabolism response to butanol } \\
\text { stress. }\end{array}$ & $\begin{array}{l}\text { Overexpression of spo0A, } \\
\text { responsible for the transcription } \\
\text { of solvent formation genes }\end{array}$ \\
\hline C. acetobutylicum & Butanol & Glucose & $70.8 \%$ & n.d. & $13.6 \mathrm{~g} \mathrm{~L}^{-1}$ & $\begin{array}{l}\text { Reduction of acetone production } \\
\text { from } 2,83 \mathrm{~g} \mathrm{~L}^{-1} \text { to } 0,21 \mathrm{~g} \mathrm{~L}^{-1} \text { and } \\
\text { enhanced butanol yield from } 57 \% \\
\text { to } 70.8\end{array}$ & $\begin{array}{l}\text { Disruption of the acetoacetate } \\
\text { decarboxylase gene (adc) } \\
\text { avoiding acetone production } \\
\text { and optimization of medium }\end{array}$ \\
\hline S. cerevisiae & Ethanol & $\begin{array}{l}\text { Glucose plus } \\
\text { HMF (inhibitor) }\end{array}$ & $0.43 \mathrm{~g} \mathrm{~g}^{-1}$ & $0.61 \mathrm{~g} \mathrm{~g}^{-1} \mathrm{~h}^{-1}$ & n.d & $\begin{array}{l}\text { Four times higher specific uptake } \\
\text { rate of HMF and } 20 \% \text { higher specific } \\
\text { Ethanol productivity }\end{array}$ & $\begin{array}{l}\text { Overexpression of alcohol } \\
\text { dehydrogenases } \mathrm{ADH} 6 \text { or } \\
\mathrm{ADH1} \text {-mutated }\end{array}$ \\
\hline S. cerevisiae & Ethanol & $\begin{array}{l}\text { Spruce } \\
\text { hydrolystae }\end{array}$ & n.d & $0.39 \mathrm{~g} \mathrm{~g}^{-1} \mathrm{~h}^{-1}$ & n.d & $\begin{array}{l}\text { HMF conversion rate and ethanol } \\
\text { productivity for the engineered } \\
\text { strains four to five times and } 25 \% \\
\text { higher than for the control strain. }\end{array}$ & $\begin{array}{l}\text { Overexpression of alcohol } \\
\text { dehydrogenases ADH6 or } \\
\text { ADH1-mutated }\end{array}$ \\
\hline
\end{tabular}

Reference 
Table 1 Selected examples of four major target categories where genetic engineering strategies were applied to improve product formation by

microorganisms (Continued)

\begin{tabular}{|c|c|c|c|c|c|c|c|c|}
\hline E. coli XW068(pLO/4319) & Lactate & Xylose plus HMF & $\begin{array}{l}85 \% \text { of the } \\
\text { theoretical } \\
\text { maximum }\end{array}$ & n.d. & n.d & $\begin{array}{l}\text { Furfural tolerance increased by } 50 \% \text {. } \\
\text { Minimal growth and lactate } \\
\text { production occurred after } 120 \mathrm{~h} \\
\text { for the control strain }\end{array}$ & $\begin{array}{l}\text { Overexpression of NADH-dependent } \\
\text { propanediol oxidoreductase (FucO) }\end{array}$ & [15] \\
\hline \multicolumn{9}{|c|}{ Increasing substrate uptake range } \\
\hline E. coli & Ethanol & Xylose & $0.48 \mathrm{~g} \mathrm{~g}^{-1}$ & $2.00 \mathrm{~g} \mathrm{~g}^{-1} \mathrm{~h}^{-1}$ & $43 \mathrm{~g} \mathrm{~L}^{-1}$ & $\begin{array}{l}\text { Rapid co-fermentation due to } \\
\text { reduced repression of xylose } \\
\text { metabolism by glucose, and } 60 \% \\
\text { less time required for fermentation } \\
\text { of } 5 \text {-sugars mix to ethanol. }\end{array}$ & $\begin{array}{l}\text { Deletion of methylglyoxal synthase } \\
\text { gene ( } m g s A) \text {, involved in sugar } \\
\text { metabolism }\end{array}$ & [16] \\
\hline Lactobacillus plantarum & Lactic Acid & Corn starch & $0.89 \mathrm{~g} \mathrm{~g}^{-1}$ & $4.51 \mathrm{~g} \mathrm{~g}^{-1} \mathrm{~h}^{-1}$ & $86 \mathrm{~g} \mathrm{~L}^{-1}$ & $\begin{array}{l}\text { First direct and efficient fermentation } \\
\text { of optically pure D- lactic acid from } \\
\text { raw corn starch reported }\end{array}$ & $\begin{array}{l}\text { Deletion of L-lactate dehydrogenase } \\
\text { gene (IdhL1) and expression of } \\
\text { Streptococcus bovis } 148 \text { a-amylase } \\
\text { (AmyA) }\end{array}$ & [17] \\
\hline S. cerevisiae & Ethanol & Xylose & $0.43 \mathrm{~g} \mathrm{~g}^{-1}$ & $0.02 \mathrm{~g} \mathrm{~g}^{-1} \mathrm{~h}^{-1}$ & $7.3 \mathrm{~g} \mathrm{~L}^{-1}$ & $\begin{array}{l}\text { Higher ethanol yields than XR/XDH } \\
\text { carrying strains }\end{array}$ & $\begin{array}{l}\text { Overexpression of Piromyces sp } \\
\text { xylose isomerase (XI) }\end{array}$ & [18] \\
\hline S. cerevisiae & Ethanol & Xylose & $0.33 \mathrm{~g} \mathrm{~g}^{-1}$ & $0.04 \mathrm{~g} \mathrm{~g}^{-1} \mathrm{~h}^{-1}$ & $13.3 \mathrm{~g} \mathrm{~L}^{-1}$ & $\begin{array}{l}\text { Higher specific ethanol productivity } \\
\text { and final ethanol concentration than } \\
\mathrm{XI} \text { carrying strains }\end{array}$ & $\begin{array}{l}\text { Overexpression of xylose } \\
\text { reductase (XR) and xylitol } \\
\text { dehydrogenase (XDH) } \\
\text { enzymes from Scheffersomyces } \\
\text { stipitis }\end{array}$ & [19] \\
\hline E. coli & Butanol & Glucose & $6.1 \%$ & $0.02 \mathrm{~g} \mathrm{~g}^{-1} \mathrm{~h}^{-1}$ & $1.2 \mathrm{~g} \mathrm{~L}^{-1}$ & $\begin{array}{l}\text { Anaerobic production of butanol by } \\
\text { a microorganism expressing genes } \\
\text { from a strict aerobic organism }\end{array}$ & $\begin{array}{l}\text { Expression of C. acetobutylicum } \\
\text { butanol pathway sinthetic genes } \\
\text { in E. coli }\end{array}$ & [20] \\
\hline \multicolumn{9}{|c|}{ Generation of new products } \\
\hline E. coli & $\begin{array}{l}\text { Fatty acid ethyl } \\
\text { esters (FAEEs) }\end{array}$ & Glucose & $7 \%$ & n.d. & $30.7 \mathrm{~g} \mathrm{~L}^{-1}$ & $\begin{array}{l}\text { Tailored fatty ester (biodiesel) } \\
\text { production }\end{array}$ & $\begin{array}{l}\text { Heterologous expression of a } \\
\text { "FAEE pathway" engineered in } \\
\text { E. coli }\end{array}$ & [21] \\
\hline S. cerevisiae & Butanol & Galactose & n.d & n.d & $2.5 \mathrm{mg} \mathrm{L}^{-1}$ & $\begin{array}{l}\text { First demonstration of n-butanol } \\
\text { production in S. cerevisiae }\end{array}$ & $\begin{array}{l}\mathrm{N} \text {-butanol biosynthetic pathway } \\
\text { engineered in S. cerevisiae }\end{array}$ & [22] \\
\hline E. coli K12 & 1,3-propandiol & Glycerol & $90.2 \%$ & $2.61 \mathrm{~g} \mathrm{~g}^{-1} \mathrm{~h}^{-1}$ & $104.4 \mathrm{~g} \mathrm{~L}^{-1}$ & $\begin{array}{l}\text { Substantially high yield and } \\
\text { productivity efficiency of 1,3-PD } \\
\text { with glycerol as the sole source } \\
\text { of carbon }\end{array}$ & $\begin{array}{l}\text { Heterologous overexpression of } \\
\text { genes from natural producers of } \\
\text { 1,3-PDO }\end{array}$ & [23]. \\
\hline
\end{tabular}

*expressed in g product per $\mathrm{g}$ substrate or\% of maximum theoretical; n.d. not determined; n.c. not calculated. 
that there are $10^{30}$ microorganism cells in the Earth. That is more than stars in the universe. And like in the universe, we only know a small fraction of those, and have characterized even fewer. Indeed, the vast microbial diversity in microorganism collections world-wide still remains unexploited and in the wild unknown species relies an enormous unknown potential.

The discovery of new genes, pathways, enzymes and characteristics in newly discovered and described wild organisms, can be applied in the development of new production processes. For instance, Pichia ciferrii was recognized as a potential producer of sphingolipids, including sphingosine, since genes encoding enzymes of the biosynthetic pathway were identified. However, no detectable amounts of sphingosine were produced by the wild type strain. Thus, metabolic engineering strategies including the implementation and improvement of a metabolic pathway for the conversion of sphinganine to sphingosine were used to develop a final strain capable of producing approximately $240 \mathrm{mg} . \mathrm{L}^{-1}$ triacetylated sphingosine (TriASo) in shake flasks and up to $890 \mathrm{mg}$. $\mathrm{kg}^{-1}$ in lab-scale fermentation. Further improvement of such strain could lead to even higher concentrations of sphinganine and sphingosine for cosmetic and pharmaceutical applications [30]. These results are still preliminary for industrial application, but they clearly demonstrate the potential of bioprospecting for developing bioprocesses.

Most certainly, encountering the complete ideal wild microorganism to be used in a specific biorefinery is a challenging mission. Scarcely a wild microorganism will have all desired traits to be employed in a biorefinery. Thus, genetic engineering strategies shall be used to design an ideal host, improving substrate uptake range and product formation, increasing tolerance, yields and rates and allowing production of new chemicals by a specific strain. In the next sections, strategies to develop such microorganisms for industrial processes applications are presented and discussed.

\section{Genetic improvement of microorganisms}

Bioprocesses require microbial strains that are able to tolerate several different stresses while keeping high yields and productivity. In addition, in order to develop and keep viable bioprocesses, the microbial strains employed or envisioned to be used need constant genetic improvement for achieving or keeping high production rates. For instance, even though the yeast $S$. cerevisiae is used for more than 30 years in Brazilian bioethanol industry, each year improved strains for the process are selected [31]. On the other hand, wild strains that contain desirable characteristics for biotechnological application usually have very low production rates or are very sensitive to the industrial conditions. Thus, different strategies have been applied to genetically improve microorganisms to solve problems such as the ones listed above, and directly or indirectly increase productivity and consequently the profitability of the bioprocess. Four major target categories where genetic and evolutionary engineering strategies may be applied to improve product formation by microorganisms are: i) driving carbon flux, ii) increase tolerance to toxic compounds, iii) increase of substrate uptake range and iv) generation of new products (Figure 1). Following, each of these targets is discussed.

\section{Driving carbon flux}

Naturally, microorganisms have their metabolic pathway optimized to sustain maximal growth and outcome competitors in the environment. Thus, production of a desired chemical usually is reduced during cell growth (expenses of carbon and energy sources) and by-product formation. Thus, a common target for modifications that directly affects microorganism's productivity is driving carbon flux through a specific pathway towards the desired product.

Microorganisms from the most different groups, from bacteria and yeast to filamentous fungi, have been genetically modified to increase production of a desired biofuel or chemical compound. Nowadays, strains that are able to produce a variety of chemical compounds in concentrations as high as above $90 \% \mathrm{~m} / \mathrm{m}$ of the theoretical maximum are available (Table 1) (Figure 2). The strategies to increase product formation generally include a series of modifications in the microorganism metabolism, achieved by overexpression or knockout of enzymes in the producing pathway [13,32], changing redox balancing of the cell by redirecting carbon fluxes from NADPH- to NADH consuming reactions [33-36], engineering global transcription machinery [37] and others (Table 1). All these types of modification were employed, for instance, to obtain $S$. cerevisiae strains that are able to produce ethanol from sugars that are present in lignocellulosic hydrolysates [38]. S cerevisiae strains able to ferment lignocellulosic hydrolysates rich in xylose and produce ethanol with yields up to $0.44 \mathrm{~g}$ ethanol/g sugar (86\% of theoretical maximum) were obtained [38]

\section{Increased tolerance to the substrate}

Another common trait that may hamper product formation by microbial strains is their low tolerance to substrate or fermentation end-product. Indeed, the fermentation medium may impose a harsh environment for the microorganism and consequently, an important trait to define the strain to be used in an industrial process is its tolerance level to toxic compounds. When tolerant strains are not available for the desired process, genetic engineering strategies may be applied to improve strain response for inhibitory compounds. A good example of such is the 
improvement of strains for production of biofuels and chemicals from lignocellulosic hydrolysates.

Lignocelulose is composed of the polymers cellulose and hemicellulose, and the macromolecule lignin. Prior to fermentation, lignocellulosic biomass must be submitted into a pretreatment to reduce its recalcitrance. In the next step, the hydrolysis, cellulose and hemicellulose are broken down into their sugar monomers, those which should later be converted into the final product [38]. The problem is that during pretreatment and hydrolysis not only sugars are solubilized, but also, compounds that inhibit microbial metabolism may be released and formed during these steps [39]. Indeed, compounds like furaldehydes (5-hydroxymethyl-2-furaldehyde - HMF; - and 2-furaldehyde - furfural), organic acids (acetic, levulinic and furoic) and phenolic derivatives are commonly found in lignocellulosic hydrolysates. However, concentration of such compounds varies according to biomass and process conditions employed. As these inhibitors can affect microbial growth, decrease product yield and productivity; prolong lag phase of microbial growth, and reduce cellular viability $[39,40]$, several evolutionary or metabolic engineering strategies have been employed to develop strains able to tolerate them. Evolutionary engineering mimics the evolutionary mechanisms of nature, in which through variation, strains are selected according to the response to the pressure they are submitted to [40].

Evolutionary engineering strategies have been applied, for example, to generate strains with higher tolerance to specific compounds (furfural, for instance), or to lignocellulosic hydrolysates, by selecting strains with the ability to remain viable and keep growth even in presence of such compounds. Through multiple selection cycles, in presence of increasing concentrations of the selection pressure, i.e. the toxic compound, mutants with higher tolerance can be selected. To increase genetic variation in the population to be submitted to the selection, pressure mutagenic agents like UV light and EMS (Ethyl methanesulfonate) can be applied. Evolutionary engineering strategies have been commonly employed to obtain S. cerevisiae [41], P. stipitis [42][43], S. passalidarum [44] mutants which are able to ferment lignocellulosic hydrolysates with higher rates than the native strains. For instance, the yeast strain TMB3400 was grown in minimal medium containing $3 \mathrm{mM}$ furfural. Once cells reached late exponential phase they were transferred to a fresh media amended with furfural. Upon shorter lag phases the furfural concentration was increased continuously. Finally, after approximately 300 generations, single colonies were obtained, and the best isolated strain showed a lag phase of $17 \mathrm{~h}$ instead of $90 \mathrm{~h}$ for parental strain in media supplemented with $17 \mathrm{mM}$ furfural. In addition, viability tests in furfural containing medium showed that the evolved strain remained viable, whereas the parental strain showed continuously decreasing colony- forming unit capacity

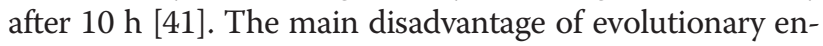
gineering resides in the fact that the genetic trait responsible for the improvement has to be identified posteriorly and thus cannot be directly transferred to another strain.

Yeast tolerance to lignocellulosic hydrolysate inhibitors has also been improved by genetic engineering strategies (Table 1) [40]. The general strategy involves identification of genes that confer resistance to inhibitors and their posterior overexpression in the desired microorganism. Yeast oxide-reductases enzymes, like alcohol dehydrogenase 6 (Adh6), and Adh1, able to convert HMF and furfural to their corresponding alcohols, when overexpressed have been shown to improve yeast growth and fermentation rates not only in medium supplemented with theses inhibitors but also in lignocellulosic hydrolysates. Genes related to regeneration of cofactors $\mathrm{NAD}(\mathrm{P}) \mathrm{H}$, and transcription factors related to stress response have also been demonstrated to increase yeast tolerance towards lignocellulosic hydrolysate inhibitors [45]. Despite the time frame required to identify genes or enzymes that confer increased tolerance, the genetic engineering strategies are advantageous because the trait can be transferred from one strain to another promptly.

\section{Increase of substrate uptake range}

The increased interest to produce fuels and chemicals from renewable resources, especially from lignocellulosic feedstocks and crude glycerol residue from biodiesel industry, made the expansion of substrate utilization another important target for genetic improvement of microorganisms [7]. Screening and genetic engineering of wild- and well-known microbial strains to increase production of fuels an chemicals from substrates previously not- or poorly utilized have gained much attention lately $[2,46]$.

A better utilization of lignocellulosic feedstocks for fuels and chemicals production requires xylose utilization. This pentose sugar is present in several biomasses and it is the second most abundant sugar in many of them. In sugar cane bagasse, for instance, xylose corresponds to up to $30 \%$ of the sugars present in the biomass [47]. Thus, xylose utilization in biotechnological processes is desirable and might contribute considerably to the economic viability of the process. In this context, second generation bioethanol production from xylose with $S$. cerevisiae is one of the most evaluated bioprocess. As this yeast is widely used in alcohol industries, including first generation bioethanol production in Brazil, but it is not able to ferment pentoses, many strategies to construct xylosefermenting S. cerevisiae strains have been employed. Among these, introduction and improvement of xylose catabolic pathways; increase sugar uptake rate by overexpression of 
transporters; changing redox metabolism; and others as reviewed by Van Maris et al. [5] and Hahn-Hägerdal et al. [38]. Nowadays, several yeast strains able to convert xylose to ethanol are available, either with reductase -dehydrogenase or xylose isomerase pathway, with yields around 90\% from the theoretical maximum, (Table 1) [48].

Production of biodiesel by (trans)esterification of oils and fats results in approximately one ton of crudeglycerol from every ten tons of biodiesel produced. As biodiesel production increased worldwide, glycerol availability did too and its prices in the market decreased. Thus, microbial processes to convert glycerol into renewable fuels and chemicals have been considered. Indeed, several groups demonstrated the potential of bacteria utilization, as well as yeast and filamentous fungi for production of ethanol, butanol, 1,3-propanediol, polyols and other chemicals from glycerol (Table 1) (Figure 2). This subject has been recently reviewed by Almeida et al [46] and Yang [49].

\section{New products}

In addition to increased production rates by redirecting carbon fluxes, increase of substrate uptake ranges and improving tolerance to inhibitory compounds, genetic engineering strategies can be employed to generate microorganisms able to produce biofuels and chemicals not naturally formed by their genetic and biochemical machinery. In this case, enzymes and pathways from one organism can be transferred to the desired microbial host, which ultimately will produce the desired compound. Nowadays, there are several examples of engineered microorganisms for production of compounds such as building block chemicals (compounds from which a big number of molecules of interest can be obtained) rather than bioethanol in this category (Table 1).

Acids derived from lignocellulosic sugars have a large potential as precursors of plastics and as building block compounds [49]. Among these there is xylonic acid, an organic acid with five carbons, derived of xylose, which is naturally produced by bacteria from the genre Acetobacter, Aerobacter, Pseudomonas Gluconobacter and Erwinia. Although wild type bacteria are efficient in the xylonic acid production, they still have high nutritional requirements, and low cell biomass production yields, which makes their utilization in industrial processes difficult. Consequently, for the last three years, genetic engineering strategies were used to build recombinant xylonic acid producing strains of $E$. coli, S. cerevisiae, Kluyveromyces lactis and Pichia kudriavzevii [50-55]. These microorganisms were chosen as possible hosts for presenting high growth rates, simple nutritional requirements and specially yeasts, for presenting good tolerance to inhibitors found in lignocellulosic hydrolysates, as commented above [45]. Indeed, the identification of genes from different microorganisms, that code for the enzymes involved in the conversion of xylose to xylonic acid allowed construction of strains able to produce xylonic acid with yields above $90 \%$ of theoretical maximum and at high concentrations [50-55].

The number of compounds naturally produced by E. coli is limited, and this bacterium is not a natural biofuel producer. However, advances in metabolic engineering techniques have allowed the development of strains capable of producing a big variety of biofuels from different carbon sources, such as glucose, xylose, glycerol, and fatty acids $[26,56]$. An interesting example is the construction of a $E$. coli strain able to produce butanol when expressing the fermentative metabolic pathway of Clostridia acetobutylicum. The expression of six genes from this pathway (thl, hbd, crt, bcd, etfAB and adhE2) in $E$. coli was necessary to obtain a strain able to produce $139 \mathrm{mg} \mathrm{L}^{-1}$ butanol from glucose under anaerobic conditions $[26,56]$. In an independent study, Inui and co-workers also inserted different combinations of genes from C. acetobutylicum butanol pathway (thL, hbd, crt, bcd-etfB-etfA, and adhe) in E. coli. The best resulting strain was able to produce $1184 \mathrm{mg} \mathrm{L}^{-1}$ of butanol. Although the amount of butanol produced by the generated strains is around 10 times lower than what is obtained by Clostridia, these experiments show that $E$. coli is a viable host for the production of biobutanol and the power of genetic engineering [20]

\section{Conclusion}

Several microbial-based bioprocesses are currently used in industry, and new ones should be established within the biorefinery context. To meet specific demands of the industry, which requires microbial strains able to produce fuels and chemicals from different renewable resources in high yields and productivity, researchers have been constructing and genetically improving microbial strains. The focus of these improvements can be grouped in four main categories: i) driving carbon flux towards the desired pathway, ii) increasing tolerance to toxic compounds, iii) increasing substrate uptake range, and iv) generation of new products. Thanks to the advances of genomic and molecular analysis techniques, and systemic analysis tools, microorganisms able to produce a variety of biofuels and chemicals from lignocellulose and other substrates, with production capacities in magnitudes orders higher than native ones, are currently available in the literature. Further studies concerning such microorganisms and their potential, are expected to contribute significantly to the development of bioprocesses within the biorefinery concept.

Competing interests

The authors declare that they have no competing interests. 


\section{Authors' contributions}

This work was carried out in collaboration between both authors. JRMA defined the review theme; BGP and JRMA wrote, read and approved the final manuscript.

\section{Acknowledgement}

This work was financially supported by EMBRAPA (Brazilian Agricultural Research Corporation) and CNPq (Brazilian National Council for Scientific and Technological Development). BGP receive a scholarship from CAPES (Coordination for the Improvement of Higher Level Education Personnel).

\section{Author details}

${ }^{1}$ Cellular Biology Department Institute of Biological Sciences University of Brasília, 70910-900 Brasilia, DF, Brazil. Embrapa Agroenergy, Parque Estação Biológica W3 Norte, 70770-901 Brasília, DF, Brazil.

\section{Received: 1 April 2014 Accepted: 7 October 2014}

\section{Published online: 29 October 2014}

\section{References}

1. Vijayendran B (2010) Bio products from bio refineries-trends, challenges and opportunities. Lett from Ed 7:109-115

2. IEA (International Energy Agency) Bioenergy Task 42 on Biorefineries (2010) http://www.iea-bioenergy.task42-biorefineries.com/

3. Borregaard Website. http://www.borregaard.com/ Accessed 01 Aug 2014

4. Fischer CR, Klein-Marcuschamer D, Stephanopoulos G (2008) Selection and optimization of microbial hosts for biofuels production. Metab Eng 10:295-304

5. Van Maris AJ A, Winkler AA, Kuyper M, de Laat WT AM, van Dijken JP, Pronk JT (2007) Development of efficient xylose fermentation in Saccharomyces cerevisiae: xylose isomerase as a key component. Adv Biochem Eng Biotechnol 108(2007):179-204

6. Goffeau A, Barrell BG, Bussey H, Davis RW, Dujon B, Feldmann H, Galibert F, Hoheisel JD, Jacq C, Johnston M, Louis E, Mewes HW, Murakami Y, Philippsen P, Tettelin H, Oliver SG (1996) Life with 6000 genes. Science 274:546-567

7. Durnin G, Clomburg J, Yeates Z, Alvarez PJJ, Zygourakis K, Campbell P, Gonzalez R (2009) Understanding and harnessing the microaerobic metabolism of glycerol in Escherichia coli. Biotechnol Bioeng 103:148-161

8. Mazumdar S, Clomburg JM, Gonzalez R (2010) Escherichia coli strains engineered for homofermentative production of D-lactic acid from glycerol. Appl Environ Microbiol 76:4327-4336

9. Causey TB, Zhou S, Shanmugam KT, Ingram LO (2003) Engineering the metabolism of Escherichia coli W3110 for the conversion of sugar to redox-neutral and oxidized products: homoacetate production. Proc Natl Acad Sci U S A 100:825-832

10. Blankschien MD, Clomburg JM, Gonzalez R (2010) Metabolic engineering of Escherichia coli for the production of succinate from glycerol. Metab Eng 12:409-419

11. Lee SJ, Song H, Lee SY (2006) Genome-based metabolic engineering of mannheimia succiniciproducens for succinic acid production. Appl Environ Microbiol 72:1939-1948

12. Alsaker K, Spitzer T, Papoutsakis E (2004) Transcriptional analysis of spo0A overexpression in clostridium acetobutylicum and its effect on the cell's response to butanol stress. J Bacteriol 186:1959-1971

13. Jiang $Y, X u C$, Dong F, Yang $Y$, Jiang W, Yang S (2009) Disruption of the acetoacetate decarboxylase gene in solvent-producing Clostridium acetobutylicum increases the butanol ratio. Metab Eng 11:284-291

14. Almeida JRM, Röder A, Modig T, Laadan B, Lidén G, Gorwa-Grauslund M-F (2008) NADH- vs NADPH-coupled reduction of 5-hydroxymethyl furfural (HMF) and its implications on product distribution in Saccharomyces cerevisiae. Appl Microbiol Biotechnol 78:939-945

15. Wang X, Miller EN, Yomano LP, Zhang X, Shanmugam KT, Ingram LO (2011) Increased furfural tolerance due to overexpression of $\mathrm{NADH}$-dependent oxidoreductase FucO in Escherichia coli strains engineered for the production of ethanol and lactate. Appl Environ Microbiol 77:5132-5140

16. Yomano LP, York SW, Shanmugam KT, Ingram LO (2009) Deletion of methylglyoxal synthase gene (mgsA) increased sugar co-metabolism in ethanol-producing Escherichia coli. Biotechnol Lett 31:1389-1398

17. Okano K, Zhang Q, Shinkawa S, Yoshida S, Tanaka T, Fukuda H, Kondo A (2009) Efficient production of optically pure D-lactic acid from raw corn starch by using a genetically modified L-lactate dehydrogenase gene-deficient and alpha-amylase-secreting Lactobacillus plantarum strain Appl Environ Microbiol 75:462-467

18. Kuyper M, Harhangi H, Stave A, Winkler A, Jetten M, Delaat W, Denridder J, Opdencamp H, Vandijken J, Pronk J (2003) High-level functional expression of a fungal xylose isomerase: the key to efficient ethanolic fermentation of xylose by? FEMS Yeast Res 4:69-78

19. Karhumaa K, Garcia Sanchez R, Hahn-Hägerdal B, Gorwa-Grauslund M-F (2007) Comparison of the xylose reductase-xylitol dehydrogenase and the xylose isomerase pathways for xylose fermentation by recombinant Saccharomyces cerevisiae. Microb Cell Fact 6:5

20. Inui M, Suda M, Kimura S, Yasuda K, Suzuki H, Toda H, Yamamoto S, Okino S, Suzuki N, Yukawa H (2008) Expression of clostridium acetobutylicum butanol synthetic genes in Escherichia coli. Appl Microbiol Biotechnol 77:1305-1316

21. Steen EJ, Kang Y, Bokinsky G, Hu Z, Schirmer A, McClure A, Del Cardayre SB, Keasling JD (2010) Microbial production of fatty-acid-derived fuels and chemicals from plant biomass. Nature 463:559-562

22. Steen EJ, Chan R, Prasad N, Myers S, Petzold CJ, Redding A, Ouellet M, Keasling JD (2008) Metabolic engineering of Saccharomyces cerevisiae for the production of n-butanol. Microb Cell Fact 7:36

23. Tang X, Tan Y, Zhu H, Zhao K, Shen W (2009) Microbial conversion of glycerol to 1,3-propanediol by an engineered strain of Escherichia coli. Appl Environ Microbiol 75:1628-1634

24. Blattner FR (1997) The complete genome sequence of Escherichia coli K-12. Science 277(80):1453-1462

25. Buschke N, Schäfer R, Becker J, Wittmann C (2013) Metabolic engineering of industrial platform microorganisms for biorefinery applications-optimization of substrate spectrum and process robustness by rational and evolutive strategies. Bioresour Technol 135:544-554

26. Clomburg JM, Gonzalez R (2010) Biofuel production in Escherichia coli: the role of metabolic engineering and synthetic biology. Appl Microbiol Biotechnol 86:419-434

27. Ingram LO, Conway T, Clark DP, Sewell GW, Preston JF (1987) Genetic engineering of ethanol production in Escherichia coli. Appl Environ Microbiol 53:2420-2425

28. Chemicals Technology. The Stan Mayfield Pilot Plant Website. http://www chemicals-technology.com/projects/stan-mayfield-biorefinery-pilot-plant/ Accessed 01 Aug 2014

29. Alper H, Stephanopoulos G (2009) Engineering for biofuels: exploiting innate microbial capacity or importing biosynthetic potential? Nat Rev Microbiol 7:715-723

30. Börgel D, van den Berg M, Hüller T, Andrea H, Liebisch G, Boles E, Schorsch C, van der Pol R, Arink A, Boogers I, van der Hoeven R, Korevaar K, Farwick M, Köhler T, Schaffer S (2012) Metabolic engineering of the non-conventional yeast Pichia ciferrii for production of rare sphingoid bases. Metab Eng 14:412-426

31. Brown NA, de Castro P, de Castro BPF, Savoldi M, Buckeridge MS, Lopes ML, de Lima Paullilo SC, Borges EP, Amorim HV, Goldman MHS, Bonatto D, Malavazi I, Goldman GH (2013) Transcriptional profiling of Brazilian Saccharomyces cerevisiae strains selected for semi-continuous fermentation of sugarcane must. FEMS Yeast Res 13:277-290

32. Mojzita D, Wiebe M, Hilditch S, Boer H, Penttilä M, Richard P (2010) Metabolic engineering of fungal strains for conversion of D-galacturonate to meso-galactarate. Appl Environ Microbiol 76:169-175

33. Anderlund M, Nissen TL, Nielsen J, Villadsen J, Rydström J, HahnHägerdal B, Kielland-Brandt MC (1999) Expression of the Escherichia coli pntA and pntB genes, encoding nicotinamide nucleotide transhydrogenase, in Saccharomyces cerevisiae and its effect on product formation during anaerobic glucose fermentation. Appl Environ Microbiol 65:2333-2340

34. Nissen TL, Kielland-Brandt MC, Nielsen J, Villadsen J (2000) Optimization of ethanol production in Saccharomyces cerevisiae by metabolic engineering of the ammonium assimilation. Metab Eng 2:69-77

35. Roca C, Nielsen J, Olsson L (2003) Metabolic engineering of ammonium assimilation in xylose-fermenting Saccharomyces cerevisiae improves ethanol production. Appl Environ Microbiol 69:4732-4736

36. Almeida JRM, Bertilsson M, Hahn-Hägerdal B, Lidén G, Gorwa-Grauslund M-F (2009) Carbon fluxes of xylose-consuming Saccharomyces cerevisiae strains are affected differently by NADH and NADPH usage in HMF reduction. Appl Microbiol Biotechnol 84:751-761

37. Alper H, Stephanopoulos G (2007) Global transcription machinery engineering: a new approach for improving cellular phenotype. Metab Eng 9:258-267 
38. Hahn-Hägerdal B, Karhumaa K, Fonseca C, Spencer-Martins I, Gorwa-Grauslund MF (2007) Towards industrial pentose-fermenting yeast strains. Appl Microbiol Biotechnol 74:937-953

39. Almeida JR, Modig T, Petersson A, Hähn-Hägerdal B, Lidén G, Gorwa-Grauslund MF (2007) Increased tolerance and conversion of inhibitors in lignocellulosic hydrolysates bySaccharomyces cerevisiae. J Chem Technol Biotechnol 82:340-349

40. Almeida JRM, Runquist D, Sànchez i Nogué V, Lidén G, Gorwa-Grauslund MF (2011) Stress-related challenges in pentose fermentation to ethanol by the yeast Saccharomyces cerevisiae. Biotechnol J 6:286-299

41. Heer D, Sauer U (2008) Identification of furfural as a key toxin in lignocellulosic hydrolysates and evolution of a tolerant yeast strain. Microb Biotechnol 1:497-506

42. Hughes SR, Gibbons WR, Bang SS, Pinkelman R, Bischoff KM, Slininger PJ, Qureshi N, Kurtzman CP, Liu S, Saha BC, Jackson JS, Cotta M, Rich JO, Javers JE (2012) Random UV-C mutagenesis of Scheffersomyces (formerly Pichia) stipitis NRRL Y-7124 to improve anaerobic growth on lignocellulosic sugars. J Ind Microbiol Biotechnol 39:163-173

43. Liu ZL, Slininger PJ, Dien BS, Berhow MA, Kurtzman CP, Gorsich SW (2004) Adaptive response of yeasts to furfural and 5 -hydroxymethylfurfural and new chemical evidence for HMF conversion to 2,5-bis-hydroxymethylfuran. J Ind Microbiol Biotechnol 31:345-352

44. Hou X, Yao S (2012) Improved inhibitor tolerance in xylose-fermenting yeast Spathaspora passalidarum by mutagenesis and protoplast fusion. Appl Microbiol Biotechnol 93:2591-2601

45. Almeida JRM, Bertilsson M, Gorwa-Grauslund MF, Gorsich S, Lidén G (2009) Metabolic effects of furaldehydes and impacts on biotechnological processes. Appl Microbiol Biotechnol 82:625-638

46. Almeida JRM, Fávaro LCL, Quirino BF (2012) Biodiesel biorefinery: opportunities and challenges for microbial production of fuels and chemicals from glycerol waste. Biotechnol Biofuels 5:48

47. Ferreira-Leitão V, Perrone CC, Rodrigues J, Franke APM, Macrelli S, Zacchi G (2010) An approach to the utilisation of CO2 as impregnating agent in steam pretreatment of sugar cane bagasse and leaves for ethanol production. Biotechnol Biofuels 3:7

48. Hahn-Hägerdal B, Karhumaa K, Jeppsson M, Gorwa-Grauslund MF (2007) Metabolic engineering for pentose utilization in Saccharomyces cerevisiae. Adv Biochem Eng Biotechnol 108:147-177

49. Werpy T, Petersen G, Aden A, Bozell J (2004) Top value added chemicals from biomass. Volume 1-Results of screening for potential candidates from sugars and synthesis gas

50. Toivari MH, Ruohonen L, Richard P, Penttilä M, Wiebe MG (2010) Saccharomyces cerevisiae engineered to produce D-xylonate. Appl Microbiol Biotechnol 88:751-760

51. Nygård Y, Toivari MH, Penttilä M, Ruohonen L, Wiebe MG (2011) Bioconversion of $\mathrm{d}$-xylose to d-xylonate with Kluyveromyces lactis. Metab Eng 13:383-391

52. Liu H, Valdehuesa KNG, Nisola GM, Ramos KRM, Chung W-J (2012) High yield production of $D$-xylonic acid from $D$-xylose using engineered Escherichia coli. Bioresour Technol 115:244-248

53. Toivari $M$, Vehkomäki $M-L$, Nygård $Y$, Penttilä $M$, Ruohonen $L$, Wiebe $M G$ (2013) Low pH D-xylonate production with Pichia kudriavzevii. Bioresour Technol 133:555-562

54. Cao Y, Xian M, Zou H, Zhang H (2013) Metabolic engineering of Escherichia coli for the production of xylonate. PLoS One 8:e67305

55. Toivari MH, Nygård Y, Penttilä M, Ruohonen L, Wiebe MG (2012) Microbial D-xylonate production. Appl Microbiol Biotechnol 96:1-8

56. Atsumi S, Hanai T, Liao JC (2008) Non-fermentative pathways for synthesis of branched-chain higher alcohols as biofuels. Nature 451:86-89

doi:10.1186/s40538-014-0021-1

Cite this article as: Paes and Almeida: Genetic improvement of microorganisms for applications in biorefineries. Chemical and Biological Technologies in Agriculture 2014 1:21

\section{Submit your manuscript to a SpringerOpen ${ }^{\circ}$ journal and benefit from:}

- Convenient online submission

- Rigorous peer review

- Immediate publication on acceptance

- Open access: articles freely available online

- High visibility within the field

- Retaining the copyright to your article

Submit your next manuscript at $\gg$ springeropen.com 